Portland State University

PDXScholar

1974

\title{
Adjustment Problems of Chinese College Students in the United States
}

Terry Shu-Fang $\mathrm{Hu}$

Portland State University

Follow this and additional works at: https://pdxscholar.library.pdx.edu/open_access_etds

Part of the Social Work Commons

Let us know how access to this document benefits you.

\section{Recommended Citation}

$\mathrm{Hu}$, Terry Shu-Fang, "Adjustment Problems of Chinese College Students in the United States" (1974). Dissertations and Theses. Paper 1723.

https://doi.org/10.15760/etd.1722

This Thesis is brought to you for free and open access. It has been accepted for inclusion in Dissertations and Theses by an authorized administrator of PDXScholar. Please contact us if we can make this document more accessible: pdxscholar@pdx.edu. 
LD4349

. A84

1974

.149

PSU Library

ADJUSTMENT PROBLEMS OF CHINESE COLLEGE STUDENTS IN

THE UNITED STATES

by

TERRY SHU-FANG HU

A report submitted in partial fulfillment of the requirements for the degree of

MASTER OF

SOCIAL WORK

Portland State University

1974

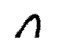


TABLE OF CONTENTS

PAGE

CHAPTER

I HYPOTHESES

Hypotheses Related to Study 1

Hypotheses Related to Marriage

II METHODOLOGY 10

The Questionnaire 10

Administrative Procedures 10

Statistical Design 11

III RESULTS

The Accepted Hypotheses 13

The Rejected Hypotheses 16

The Other Findings

IV DISCUSSION OF RESULTS - 28

Implications of Social Work Practice - 28

Recommendations for Further Study - 33

BIBLIOGRAPHY

APPENDIX 36 


\section{LIST OF TABLES}

TABLE

PAGE

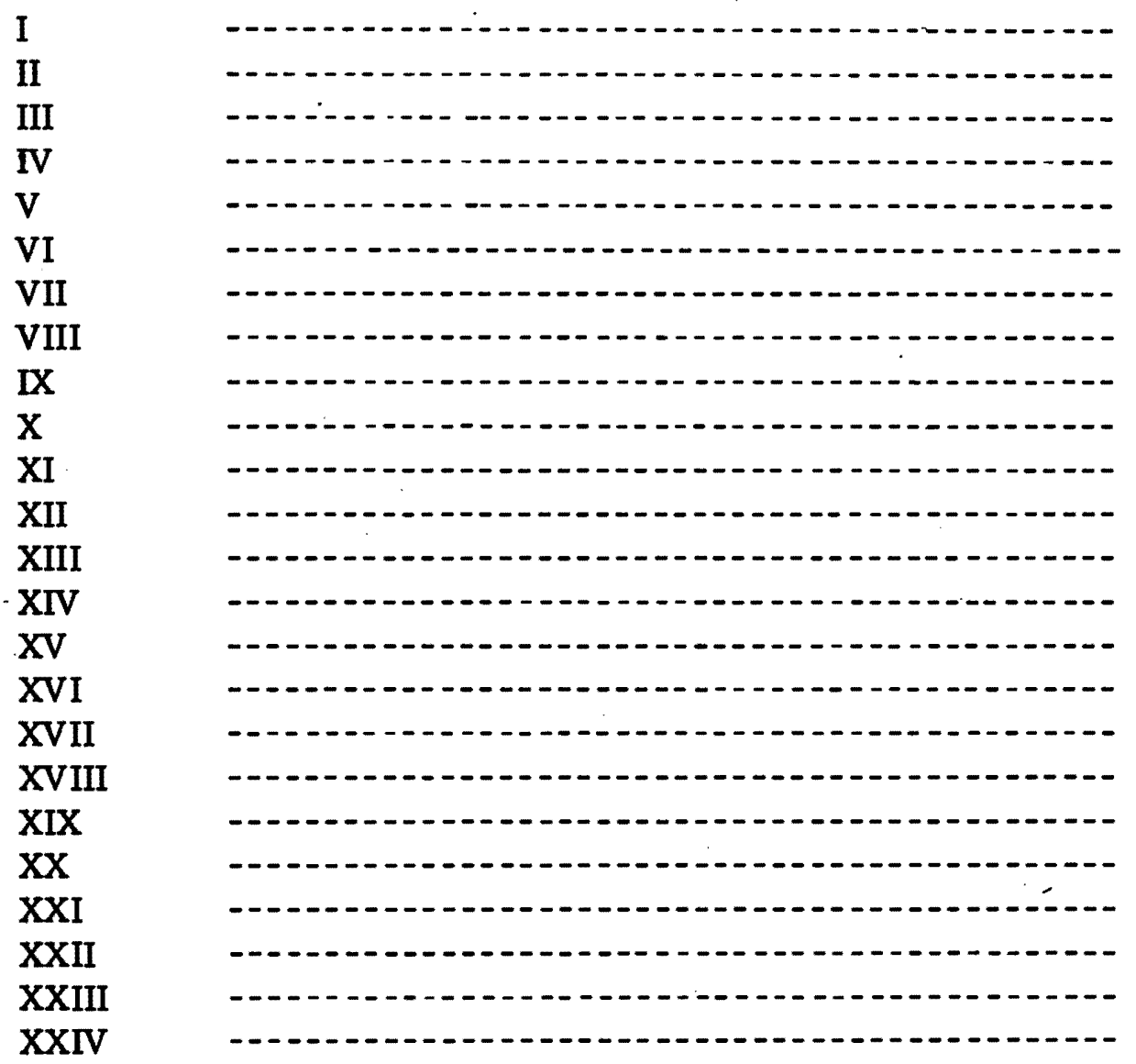




\section{CHAPTER I}

\section{HYPOTHESES}

This is a study of selected adjustment problems among Chinese students from Hong Kong and Taiwan attending two Oregon universities, Portland State University and University of Oregon, with data gathered by questionnaire, in the school year 1973-1974.

The author, as a person brought up in a middle class Chinese family in Taiwan, Republic of China for twenty-two years and as a foreign student in the United States for about two years has developed a certain understanding of Chinese college students through listening, observation, talking and personal experience. It is true that foreign students have to face more problems than most fellow students. The former tries to adjust to the new environment on campus and off campus, which is a very difficult job that dema nds a higher level of maturity, flexibility, self-esteem and self-confidence. The hypotheses of this study were formed with the purposes of defining the areas where adjustment problems existed and further deciding the implications for social work practice, to help students reduce adjustment difficulties. My primary concern centers on the psychological adequecy of Chinese students in dealing with the novel unfamiliar situations. HYPOTHESES RELATED TO STUDY 
It was assumed for testing that housing arrangement, language difficulty, major study field, feeling of being in the group, and homesickness were more or less related to one another, as follows:

HYPOTHESIS l: As far as learning English is concerned, the student who lives with American(s) feels that he improves himself in English more than the students who live with Chinese feel.

HYPOTHESIS 2: The student who is able to understand or to be understood by his professors and classmates feels that he is accepted by them, otherwise he feels he is isolated.

HYPOTHESIS 3: As far as English difficulty is concerned, the student who is a major in a social field feels more difficulty in keeping up with American students than the student who is a major in a technical field does. HYPOTHESIS 4: Most Chinese students consider themselves good students academically, no matter how they feel about ability in English. HYPOTHESIS 5: The longer a student has been in the United States, the less he feels homesick.

The rationale for these hypotheses is as follows. That the proper housing of foreign students is an important factor in a satisfactory college experience goes without saying. It is natural and understandable that foreign students would like to live with their fellow people because similar daily living habits, the same conversational language, and the feeling of being in the same boat make life "easier". But, in the mean time, they have missed the opportunities which can be provided by living with American students or family to practice English often, 
to learn E nglish well, and to learn the customs of the country. According to Helen Clarke and Martha Ozawa (1970), the common opinion of both foreign students and faculty regarding foreign student problems is that inability with English is one of the biggest, most critical problems. ${ }^{1}$ Learning to communicate intelligently in English is an indispensable factor in American education. Students who do not really understand the ideas presented by their American associates are greatly handicapped. Although it is assumed that a foreign student should have learned English well before he came to this country, there is a vast defference between having a reading knowledge of a language and ears trained to hear the spoken language. Most of the Chinese students from Taiwan very seldom or never had any chance to speak English home, althouth English was a require course in high school and the first year of college. Hong Kong students who were from English schools felt less difficulty with English.

Peter F. Drucker (1952), a specialist in human relations, once said that the basic skill taught in college was the ability to organize and express ideas in writing and speaking. ${ }^{2}$ Cora Du Bois said (1956), " The degree of command of English which a foreign student brings with him and acquires during his sojourn is one of the most significant skills, and also a symptom of

${ }^{1}$ Clarke, Helen. and Ozawa, Martha., The Foreign Student in the United States --with Special Reference to Martha, the University of Winsconsin, Wisconsin, 1970, p. 31 .

${ }^{2}$ Du Bois, Cora., Foreign Students and Higher Education in the United States, American Council on Education, Washington D.C., 1956, p. 54 . 
his capacity to understand and to deal with the American environment, particularly the highly verbalizing environment of American colleges." norms is a function of language. There is a time to speak and a time to keep silence. The rules governing the occasions for speech and silence differ from culture to culture. Usually Chinese students are not particularly encouraged to speak up or ask questions in classroom. It is a traditional way, maybe not an accepted way according to American thinking, that we show trust and respect for our teachers. But in American colleges a student should be able to participate in group discussions, to express and share his ideas with his professors and classmates. Lea rning is not just memorizing and parroting any more as we have been trained to do. It involves questioning and debate. A foreign student with language difficulty can not verbally participate with his class, while he may even not understand what people are talking about or he may not be able to express himself well in English. These experiences happened to me constantly during my first year of stay here. I felt sorry for American professors who were openly challenged by students because they had different points of view. I could not really understand what was discussed back and forth. When I did figure out what was going on and had something in my mind that I wanted to speak up, I either could not find the right way to put it or was afraid that people would laugh at me for my poor English. All the time I wished I could have been understood by

${ }^{1} \mathrm{Du}$ Bois, Cora., Foreign Students and Higher Education in the United States, American Council on Education, Washington D.C., 1956, p. 82 . 
speaking in Chinese. I felt frustrated and depressed not only because I was not able to conform to the norms in classroon, but also because I did not want to be considered an inadequate student.

Without a common body of symbols the communication and establishment of meaningful, effective, and reciprocal relationships can hardly be established. Most Chinese students attending an American college just sit in classroom, listen to professors, take notes, do research in the laboratory and study in the library. They do not feel that they relate to or are accepted by the other American students. The more a foreign student withdraws, the less he practices and improves English, and the more he feels isolated ingroups. It is not seldom that a foreign student would say," I have no friends and I feel lonely and homesick. In a crowd I feel lost and no classmates attempted to help."

Differences between English and a foreign language are sufficient to make translation often difficult and sometimes impossible. A foreign student is much slower than American studentsas far as the speed of English reading and writing is concerned. His study may take double or triple the time for American students. After making all these efforts if he does not receive good grades, which are' usually considered the symbols of success, his sense of self-confidence and selfesteem is decreased. Chinese students had passed many qualifying examinations with success before they came to America. There are good reasons to believe that they were average or above average students back home. They are intelligent enough to receive higher educationi. I believe somehow most of them manage to keep their self images as a fairly good student in American colleges no matter 
how insecure they feel about English and no matter how hard they have to study.

I have been often told by Chinese students who major in mathematics, chemistry or physics, that it is not really hard for them to get better or even the best grades among classmates, although very evidently they can hardly communicate with them in English. So I assumed that the students who were concerned with physical sciences or laboratory techniques that do not primarily depend on spoken English feel less difficulty in keeping up with American students than do the students of social sciences who have strong personal needs to relate themselves to a wide social environment and are anxious to feel the pulse of American life. Basically the command of oral communication in English for the former is not so urgent as it is for the latter.

Human beings are good at avoiding unhappy experiences, to protect themselves. A foreign student, first come to a new country for study has many difficulties to struggle against. He can experience a considerable amount of feelings of helplessness mixed with the feelings of depression. Naturally he misses his home. He wants to go back to the place where he can be well taken care of, can feel secure and warm. Chinese are convinced that there is no place that can be better than home. The traditional family ties still pretty strongly exist in Taiwan and Hong Kong. I came to believe that the longer a student stays in America, the more he learns to use the new environment in order to take advantage of and adapt to it, the less he has adjustment problems, consequently the less he feels homesick. 
HYPOTHESES RELATED TO MARRIAGE

Making friends with opposite sex is also a major concern of Chinese college students. It was assumed that different social and parental attitudes towards marriage by male and female students influenced the different concerns of male and female students, as follows:

HYPOTHESIS 6: As far as getting married to an American is concerned, female students do not get parental opposition so much as male students do. HYPOTHESIS 7: There is a tendency that an unmarried male student plans to look for his potential spouse home instead of in the United States, while an unmarried female student plans to look for one in the United States. HYPOTHESIS 8: An unmarried female student is more concerned about her marriage, an unmarried male student is more concerned about his achieving a degree.

The rationale for this set of hypotheses comes from a number of considerations. Nowadays in Chinese society parents and the elders in a family are still the authority figures. Their advice is respected and followed by the young not only because it is an important part of Chinese traditional culture that parents' past experiences a re valued by the young, but also because Chinese always put family before individuals. For example, if $\mathrm{HE}$ wishes to be a professional musician, but SON is expected to be a doctor by his family, very probably he will go to medical school rather than school of music. Even if we are in the United States now, the physical distance has changed little this well-formed 
pattern of relationship between us and our families. Once I was told by one of my Chinese friends, "I do not really want to study any more. But I know a doctoral degree means a lot to my parents. I will go to a bigger college and get the degree so my parents will feel proud of me." Surely the popular individualism in this country has offered us various opportunities in pursuit of our own happiness, to taste more new experiences, to touch a wider world without the boundaries of tradition. But when it comes to marriage, which is considered by Chinese the most essential and serious affair of one's life, we wish to receive parental blessings as well as their permission. An unmarried Chinese student realizes that his girlfriend may someday become not only his wife but also his parents' daughter-in-law. No matter whether the two families plan to live together afterwards or not, in fact mostly they do not any more, he wants her to be accepted by his family. It is usually not hard to avoid conflicts between the two generations because he has internalized his parents' criteria of a "good" girl. The above mentioned situation applies to young females as well.

Most Chinese, especially the older generation, do not believe in mixed marriage as they have not been exposed to it much. Traditionally, the Chinese family lays more emphasis on sons because they carry the family's name to the next generation. As Maurice Freedman said (1970), "In general, the treatment of a girl is not dramatically different from that of her brothers. The attitudes her parents hold toward her, however, are quite different. The rigid standards of respect and obedience her brother must adhere to as an adult are of less value in her, since she will be in another household. "l I assumed that 
as far as getting married to an American is concerned, female students would get parental opposition, but not so much as male students do.

It is not easy for a foreign student to look for his potential spouse within the same nationality, since usually his minority group is not numerous enough for him to make a choice among many. There are not many graduate schools in Taiwan and the enrollment of a graduate school is very limited. It is a law of the Education Department of the Taiwan government that only college graduates are formally qualified to apply to study abroad. So most Chinese students from Taiwan are graduate students and will receive a master's degree within two or three years. Chinese believe that a husband should have received more or the same education as his wife, so that the family can keep a better balance. Since there are only few chances for a female student who has her master's degree to look for her potential spouse back home with a higher or the same degree, I hypothesized that she would plan to look for one in the United States. As for a male student the higher the education he has received, the more easily he or his family can look for a girl or a wife for him. Besides, the girls in Taiwan are somewhat favorably impressed with boys who have studied in the United States. Consequently I also assumed that a female student was more concerned about her marriage and a male student was more concerned about his achieving a degree.

${ }^{1}$ Freedman, Maurice. , Family and Kinship in Chinese Society, Stanford University Press, California, 1970, p. 45 . 
to me right after they were filled out. I believed that this way I would have a better return than from sending questionnaires by mail. I chose Portland State University and University of Oregon as the population of my research because of the geographical closeness and also because of the fact that there were many Chinese students at both colleges.

At the University of Oregon questionnaires were distributed one day, when there was a special Chinese students gathering. I handed out seventy questionnaires and received forty-seven back.

With the help of the president of the Chinese Students Association at Portland State University and another graduate student from Hong Kong, the questionnaires were handed out within about a week. Twenty-two out of thirty were returned, within a month.

The sample was one of opportunity, non-random, with no feasible way of ascertaining representativeness. The Chinese student population at the University of Oregon was about one hundred and eighty. At Portland State University the Hong Kong population was unknown, but the Taiwan population was close to thirty. Thus the sample was not adequate for drawing inferences about Chinese students as a whole from either university.

\section{STATISTICAL DESIGN}

The chi-square was used to test the hypotheses, at the .05 level of confidence. Descriptive statistics were tabled in terms of numbers and percentages with the sample as base. 


\section{CHAPTER III}

\section{RESULTS}

Out of a total of sixty-nine responses, thirty-two of the sample were male and thirty-seven were female. Forty-seven were students at the University of Oregon and twenty-two were students at Portland State University. Thirty-four were from Taiwan and thirty-five were from Hong Kong. ( See Tables I, II, and III.)

TABLE I

DISTRIBUTIONS BY SEX

$\begin{array}{lcr}\text { Category } & \text { Frequency } & \text { Percent } \\ \text { Male } & 32 & 46 \% \\ \text { Female } & 37 & 54 \% \\ \text { Total } & 69 & 100 \%\end{array}$

TABLE II

DISTRIBUTIONS BY COLLEGE

\section{Category}

University of Oregon

Portland State University

Total
Frequency

47

22

69
Percent $68 \%$ $32 \%$ $100 \%$ 
TABLE III

\section{DISTRIBUTIONS BY HOME RESIDENCE}

Category

Frequency

Percent

Taiwan

34

$49 \%$

Hong Kong

35

$51 \%$

Total

69

$100 \%$

\section{THE ACCEPTED HYPOTHESES}

Hypothesis 2: It was hypothesized that the student who was able to understand or to be underst ood by his professors and classmates felt that he was accepted by them, otherwise he felt he was isolated.

It was found that there was a relationship between communication problem and feeling of being in the group.

The hypothesis was therefore accepted. Table IV shows this relationship. Data for this table came from questions 14 and 19 of the questionnaire.

TABLE IV

COMMUNICATION PROBLEM AND FEELING OF BEING IN THE GROUP

Communication

Problem

Often

Sometimes

Seldom

No Problem

Total
Accepted

0

$4(16 \%)$

4 (67\%)

17 (53\%)

25
Isolated

$6(100 \%)$

21 (84\%)

2 (33\%)

$15(47 \%)$

44
Total

$6(100 \%)$

25 (100\%)

6 (100\%)

32 (100\%) 
Note: Eight students who felt they were complete outsiders in their classes were categorized in "Isolated".

A test of significance was not needed because the following relationships were clea rly significant by inspection: 1. Among those with no communication problem about equal proportions felt isolated or accepted. 2. Those with communication problems (seldom, sometimes, or often) tended strongly to feel isolated. 3. With respect to communication problems and dichotomizing never and sometimes chi-square was 7.37 , significant at the .01 level. When often and sometimes were compared with seldom and never chi-square was 11.38 , significant at the .001 level, but one cell had a frequency of only 4.

Hypothesis 3: It was hypothesized that the student who was a major in a social field felt more difficulty than the student who was a maj or in a techical field in keeping up with American classmates.

It was found that thirty students were social field majors, thirty-six were technical field majors, and three were undecided. (See Table V.)

It was found that there was a relationship between major field and keeping up with American students, the technical field students felt it easier to keep up.

The hypothesis was therefore accepted. Table VI shows the relationship. 
TABLE V

DISTRIBUTIONS BY MAJOR FIELD

\begin{tabular}{lcll} 
Category & Frequency & Category & Frequency \\
Social Field & & Technical Field & \\
\hline Asian Study & 1 & Architecture & 1 \\
Business Administration & 13 & Biology & 7 \\
Business Education & 6 & Chemistry & 6 \\
Economics & 2 & Computer Science & 7 \\
History & 1 & General Science & 2 \\
Liberal Art & 1 & Mathematics & 9 \\
Music & 1 & Physics & 3 \\
Physical Education & 1 & Pre-med & 1 Total 36(55\%) \\
Psychology & 1 & & \\
Social Work & 1 & & \\
Sociology & 1 & & \\
Speech Communication & 1 Total 30(45\%)
\end{tabular}

Total

$66(100 \%)$

Note: Major-undecided students $=3$.

TABLE VI

MAJOR FIELD AND KEEPING UP WITH AMERICAN CLASSMATES

$\begin{array}{lll}\text { Difficult In Betwen } & \text { Easy }\end{array}$

$\begin{array}{llccc}\text { Social } & 9(30 \%) & 14(47 \%) & 7(23 \%) & 30(100 \%) \\ \text { Technical } & 5(13 \%) & 12(33 \%) & 19(54 \%) & 36(100 \%) \\ \text { Total } & 14 & 26 & 26 & 66 \\ \mathrm{X}^{2}=6.35 & & \mathrm{df}=2 & & \mathrm{X} .95^{2}=5.99\end{array}$


Hypothesis 4: It was hypothesized that most of the Chinese students considered themselves good students academically, no matter how much difficulty they felt about English.

It was found that no one felt he was a below-average student in his class. There was no relationship betwen language difficulty and class status.

The hypothesis was thereforeiaccepted. Table VII shows the relationship.

TABLE VII

LANGUAGE DIFFICULTY AND CLASS STATUS

Top Above Average Average Total

Difficult $2(7 \%) \quad 14(50 \%) \quad 12(43 \%) \quad-\quad 28(100 \%)$

In Between $\quad 1(4 \%) \quad 9(35 \%) \quad 16(61 \%) \quad 26(100 \%)$

Easy $\quad 3(20 \%) \quad 9(60 \%) \quad 3(20 \%) \quad 15(100 \%)$

$\begin{array}{lllll}\text { Total } & 6 & 32 & 31 & 69\end{array}$

While the assumptions of chi-square with respect to mininal cell counts are not met, the relationship is clearly strong, especially considering the lack of responses below-average.

\section{THE REJECTED HYPOTHESES}

Hypothesis 1: It was hypothesized that those students living with English speaking prople in family or domitories would see themselves as more fluent in English, as compared to those living by themselves or with other Chinese.

It was found that no relationship existed betwæn perseived English improvement and housing arrangement. Most students felt they had much improved in 
English no matter whether they lived with English speaking people or non-English speaking people.

The hypothesis was therefore rejected. Table VIII shows this relationship.

TABLE VIII

HOUSING ARRANGEMENT AND ENGLISH IMPROVEMENT

$\begin{array}{llll}\text { Much } & \text { Little } & \text { The } & \\ \text { Improved } & \text { Improved } & \text { Same } & \text { Total }\end{array}$

$\begin{array}{llll}\text { With American(s) } & 18(82 \%) & 0 & 4(18 \%)\end{array} 22(100 \%)$

With American(s) ${ }^{2}$

and Chinese

$4(100 \%) \quad 0 \quad 0 \quad 4(100 \%)$

$\begin{array}{lllll}\text { With Chinese } & 3 & 38(88 \%) & 2(5 \%) & 3(7 \%)\end{array}$

$\begin{array}{lllll}\text { Total } & 60 & 2 & 7 & 69\end{array}$

Note l: By "Americans" I meant the people who spoke the American language.

Note 2: Students who did not have a roommate were categorized according to the majority of the people living in the same apartments or dormitories.

Note 3: Students who were married and were living with their spouses were categorized to "Living with Chinese" since nobody was married to non-Chinese.

By inspection it was clear that there was no relationship with respect to homogeneity of living arrangements and how much improvement in language was felt, so tests of significance were not made. The categories of little or no improvement might include a number of types of cases, such as the already adequate (more probably from Hong Kong or transfer students), the new students with severe handicap, those with inadequate preparation in the field of study, and so on. Only $13 \%$ of the sample fell in these six possible cells, with no pattern to their distribution. 
Hypothesis 5: It w as hypothesized that the longer a student had been in the United States, the less he felt homesick.

It was found that no relationship existed between length of time in the United States and homesickness. Apparently how often a student felt homesick did not depend on how long he had been in this country.

The hypothesis was therefore rejected. Table IX shows the relationship.

TABLE IX

\section{LENGTH OF TIME IN THE UNITED STATES AND HOMESICKNESS}

$\begin{array}{lllll}\text { Year(s) } & \text { Seldom } & \text { Sometimes } & \text { Often } & \text { Total } \\ 0-1 & 5(36 \%) & 7(50 \%) & 2(14 \%) & 14(100 \%) \\ 1-2 & 3(17 \%) & 12(66 \%) & 3(17 \%) & 18(100 \%) \\ 2-3 & 2(13 \%) & 12(75 \%) & 2(13 \%) & 16(100 \%) \\ 3-5 & 3(30 \%) & 7(70 \%) & 0 & 10(100 \%) \\ 5-7 & 5(46 \%) & 4(36 \%) & 2(18 \%) & 11(100 \%) \\ \text { Total } & 18 & 42 & 9 & 69 \\ x^{2}=7.72 & \quad \mathrm{df}=8 & \mathrm{X}_{.95}{ }^{2}=15.51 & \end{array}$

Hypothesis 6: It was hypothesized that unmarried male students would ge $t$ more parental opposition than unmarried female students would, as far as getting married to Americans was concerned.

Out of the total population of sixty-nine it was found that twenty percent of the students were married and eight percent were single. Only one of the fourteen married students did not live with his spouse, who was in Taiwan. ( See Table X.)

It was found that a majority (54\%) Chinese parents were seen by students as 
against the mixed marriage of either their son or daughter. However, seven percent of parents favored, and thirty-eight percent were neutral with respect to marrying Americans as students saw it. There was no relationship between sex and the way they perceived parental attitudes toward marriage.

The hypothesis was therefore rejected. Table XI shows the relationship.

TABLE X

DISTRIBUTIONS BY SEX AND MARITAL STATUS

Married Single Total

Female

3

34

37

Male

11

21

32

Total

$14(20 \%)$

$55(80 \%)$

$69(100 \%)$

TABLE XI

SEX AND PARENTAL ATTITUDE

$\begin{array}{llll}\text { Against Neutral } & \text { Favor } & \text { Total }\end{array}$

$\begin{array}{lcccr}\text { Female } & 18(53 \%) & 14(41 \%) & 2(6 \%) & 34(100 \%) \\ \text { Male } & 12(57 \%) & 7(33 \%) & 2(10 \%) & 21(100 \%) \\ \text { Total } & 30(55 \%) & 21(38 \%) & 4(7 \%) & 55(100 \%) \\ \mathrm{X}^{2}=0.49 & \text { df }=2 & \mathrm{X} .95{ }^{2}=5.99 & \end{array}$

Hypothesis 7: It was hypothesized that more unmarried female students intended to look for their potential spouses in the United States, while more unmarried male students intended to look for their potential spouses at home.

Out of fifty-five unmarried students it was found that forty percent already had a potential spouse and the other sixty percent had not. (See Table XII.) 
A test of proportions showed no relationship between sex and location of potential spouse, among those who did not have a potential spouse.

The hypothesis was therefore rejected. Table XIII shows the relationship.

TABLE XII

DISTRIBUTIONS BY SEX AND EXISTENCE OF POTENTIAL SPOUSE $\begin{array}{lll}\text { Yes } & \text { No } & \text { Total }\end{array}$

Female

15

19

34

Male

7

14

21

Total

$22(40 \%)$

$33(60 \%)$

55 (100\%)

TABLE XIII

SEX AND LOCATION OF POTENTIAL SPOUSE

Home USA Both $\quad$ Total

$\begin{array}{lllll}\text { Female } & 2(13 \%) & 8(50 \%) & 6(37 \%) & 16(100 \%) \\ \text { Male } & 3(25 \%) & 4(33 \%) & 5(42 \%) & 12(100 \%) \\ \text { Total } & 5 & 12 & 11 & 28\end{array}$

Note: Students answered "Don't Know" $=5$.

Hypothesis 8: It was hypothesized that an unmarried female student was more concerned about her marriage, while an unmarried male student was more concerned about his achieving a degree.

It was found that there was no relationship between sex and major concern. Both male and female students, (about seven-five percent), were more concerned about their achieving a degree. But, among those students concerned about marriage females predominated, with more than twice the percentage of males. 
The hypothesis was therefore rejected. Table XIV shows the relationship.

TABLE XIV

SEX AND MAJOR CONCERN

$\begin{array}{lll}\text { Marriage } & \text { Degree } & \text { Total }\end{array}$

$\begin{array}{lccl}\text { Female } & 11(32 \%) & 23(68 \%) & 34(100 \%) \\ \text { Male } & 3(14 \%) & 18(86 \%) & 21(100 \%) \\ \text { Total } & 14 & 41 & 55 \\ \mathrm{X}^{2}=1.61 & \mathrm{df}=1 & \mathrm{x}_{.95}{ }^{2}=3.84 & \end{array}$

THE OTHER FINDINGS

Several other a spects of Chinese students' adjustment in the United States were explored in the questionnaire.

It was found that the students who felt they did not improve themselves in English had been in this country less than two years, and those who had been here over two years felt their English had been much improved. Evidently time is an important factor for the adjustment to English language. (See Table XV.)

TABLE XV

LENGTH OF TIME IN THE UNITED STATES AND LANGUAGE IMPROVEMENT

$\begin{array}{cccll} & \begin{array}{c}\text { Much } \\ \text { Improved }\end{array} & \begin{array}{c}\text { Little } \\ \text { Improved }\end{array} & \begin{array}{c}\text { The } \\ \text { Same }\end{array} & \text { Total } \\ 0-1 & 11(79 \%) & 0 & 3(21 \%) & 14(100 \%) \\ 1-2 & 12(67 \%) & 2(11 \%) & 4(22 \%) & 18(100 \%) \\ 2-3 & 16(100 \%) & 0 & 0 & 16(100 \%) \\ 3-5 & 10(100 \%) & 0 & 0 & 10(100 \%)\end{array}$


TABLE XV (Continued)

LENGTH OF TIME IN THE UNITED STATES AND LANGUAGE IMPROVEMENT

$\begin{array}{cccc}\text { Much } & \text { Little } & \text { The } & \\ \text { Improved } & \text { Improved } & \text { Same } & \text { Total }\end{array}$

$\begin{array}{ccccc}5-7 & 11(100 \%) & 0 & 0 & 11(100 \%)\end{array}$

$\begin{array}{lllll}\text { Total } & 60 & 2 & 7 & 69\end{array}$

It was found that, first, frmale students reported they felt homesick more often than male students did. Second, students from Taiwan were more homesick, as compared to those students form Hong Kong. Third, seventy-eight percent of the often-homesick group and sixty-one percent of the seldomhomesick group were students who felt they were isolated among American students. (See Tables XVI, XVII, XVIII. ) It might be surmised that lack of the sense of belonging to an immediate group would make a student feel homesick, but, for an individual who was used to being independent of his family, feeling alone in the group did not consequently produce a homesick feeling; factors were not explored.

TABLE XVI

SEX AND HOMESICKNESS

$\begin{array}{lllll} & \text { Seldom } & \text { Sometimes } & \text { Often } & \text { Total } \\ \text { Female } & 8(22 \%) & 21(56 \%) & 8(22 \%) & 37(100 \%) \\ \text { Male } & 10(31 \%) & 21(66 \%) & 1(3 \%) & 32(100 \%) \\ \text { Total } & 18 & 42 & 18 & 69\end{array}$


TABLE XVII

HOME RESIDENCE AND HOMESICKNESS

Seldom Sometimes Often Total

$\begin{array}{lllll}\text { Taiwan } & 6(18 \%) & 21(62 \%) & 7(20 \%) & 34(100 \%) \\ \text { Hong Kong } & 12(34 \%) & 21(60 \%) & 2(6 \%) & 35(100 \%) \\ \text { Total } & 18 & 42 & 9 & 69\end{array}$

TABLE XVIII

HOMESICKNESS AND FEELING OF BEING IN A GROUP

$\begin{array}{lll}\text { Accepted } & \text { Isolated }\end{array}$

$\begin{array}{llll}\text { Seldom } & 7(39 \%) & 11(61 \%) & 18(100 \%)\end{array}$

$\begin{array}{lll}\text { Sometimes } & 16(38 \%) & 26(62 \%)\end{array}$

$\begin{array}{lll}\text { Often } & 2(22 \%) & 7 .(78 \%)\end{array}$

$\begin{array}{llll}\text { Total } & 25 & 44 & 69\end{array}$

Out of the total population of sixty-nine it was found that fifty-nine students were holding or had held a job on campus or off campus. Most of the jobs were low-paid, did not require intellectual work, and did not further the students' careers. They supported themselves completely (74\%) or partially (12\%). The other ten students who did not have a job and depended on their homes' financial help entirely (14\%), had been in this country only six to eight months, except one who was a housewife had been here about two years. ( See Tables XIX, and XX. ) Economic independence and responsibility for self support have been high values in American culture, but such demands are not traditionally made on Chinese young people, especially students. We used to take parents' financial support 
for granted. According to my impressions, most Chinese students worked not because they had to economically, but because they wanted to appreciate the sense of growing up and independence.

TABLE XIX

\section{DISTRIBUTIONS BY FINANCIAL RESOURCES}

Category

Self Working and Saving

Self and Scholarship

Self andHome

Home

Total
Frequency

26

25

8

10

69
Percent

$38 \%$

$36 \%$

$12 \%$

$14 \%$

$100 \%$

TABLE XX

DISTRIBUTIONS BY JOB

\section{Category}

On Campus

Cafeteria Helper

Janitor

Language Lab Assistant

Research Assistant

Student Secretary

Teaching Assistant

Tutor
Frequency

9

1

8

4

3

9

2 Total 36

\section{Off Campus}

Busboy, Busgirl

Cannery Worker

Dishwasher

Hotel Porter

Hotel Maid

Office Worker

Salesgirl 


\section{TABLE XX (Continued)}

\section{DISTRIBUTIONS BY JOB}

Category

Off Campus

Waiter, Waitress
Frequency

20 Total 52

Total

Note: $\mathrm{N} 69,10$ students had never had a job, the other students might have had more than one job.

It was found that Chinese friends and relatives--including parents, siblings, and spouses--were main resources of problem-solving for Chinese students. Data came from question 21 of the questionnaire. Students at Portland State University and students at the University of Oregon were somewhat different in terms of where else to go to get help. At Portland State University no one ever went to a foreign student advisor for help and professors appeared to be a more important resource. While at the University of Oregon, students were more able to take advantage of their environment and got hel p from American families, American friends, school counselor, and foreign student advisor. ( See Table XXI. ) Foreign student services were mostly recognized by Chinese students in the sense that they were functions of an administrative office where students had to go in order to st ay and work in this country as a foreign student. ( See Table XXII.) 
TABLE XXI

DISTRIBUTIONS BY HELPING AGENT AND COLLEGE

$\begin{array}{lcc} & \text { PSU } & \text { UO } \\ \text { Chinese Friends } & 17 & 39 \\ \text { American Friends } & 3 & 11 \\ \text { American Family } & 3 & 9 \\ \text { School Counselor } & 1 & 4 \\ \text { Foreign Student Advisor } & 0 & 5 \\ \text { Priest or Minister } & 0 & 3 \\ \text { Professor } & 5 & 4 \\ \text { Relative } & 8 & 11 \\ \text { No one } & 1 & 2 \\ \text { Other ( God ) } & 1 & 2\end{array}$

TABLE XXII

DISTRIBUTIONS BY REASON FOR GOING TO FOREIGN STUDENT ADVISOR PSU UO

Extending Visa $\quad 15 \quad 23$

Working Permit $\quad 13 \quad 22$

$\begin{array}{lll}\text { Enrollment Certificate } & 7 & 10\end{array}$

Financial Aid $\quad 3 \quad 16$

Social Visit $\quad 1 \quad 10$

Other ( Academic Advising ) $\quad 1 \quad 5$

The majority of students both from Taiwan and Hong Kong considered themselves as coming from a middle class family. But apparently they had not given 
much thought to their future plans, such as wishing to go back home or stay in the United States after they graduated. ( See Tables XXIII, and XXIV. )

TABLE XXIII

DISTRIBUTIONS BY HOME RESIDENCE AND FAMILY SOCIAL POSITION

$\begin{array}{lllll} & \text { High } & \text { Middle } & \text { Low } & \text { Total } \\ \text { Taiwan } & 9(26 \%) & 24(71 \%) & 1(3 \%) & 34(100 \%) \\ \text { Hong Kong } & 8(23 \%) & 26(74 \%) & 1(3 \%) & 35(100 \%) \\ \text { Total } & 17 & 50 & 2 & 69\end{array}$

TABLE XXIV

DISTRIBUTIONS BY HOME RESIDENCE AND FUTURE PLAN

$\begin{array}{lcll}\text { Back } & \text { Staying } & \text { Not } & \\ \text { Home } & \text { USA } & \text { Sure } & \text { Total }\end{array}$

$\begin{array}{lllll}\text { Taiwan } & 14(41 \%) & 2(6 \%) & 18(53 \%) & 34(100 \%) \\ \text { Hong Kong } & 14(40 \%) & 4(11 \%) & 17(49 \%) & 35(100 \%) \\ \text { Total } & 28 & 6 & 35 & 69\end{array}$


CHAPTER IV

\section{DISCUSSION OF RESULTS}

\section{IMPLICATIONS OF SOCIAL WORK PRACTICE}

Certain Important Facts It was interesting to find out the common answers from the three students who reported they did not go to anybody for help when they had problems in daily life:

They were majors in technical fields -- Chemistry, Computer Science, and Architecture.

They shared room with an American student.

They were single and more concerned about achieving a degree.

They had no problem communicating in English.

They thought it was very easy to keep good grades and considered themselves above-average students at school.

They felt they were isolated in groups.

They had been holding a job on campus and off campus.

They sometimes felt homesick.

There were good reasons to believe that these three students with independent, not out-going personality might be the ones who really needed help. They did not have to get in touch with people since their studi es were not related to human relations. They felt isolated. The fact that they still sometimes felt homesick possibly indicated that there might be adjustment problems which they refused to face, or failed to recognize, or tried to handle by themselves. The problems could not be academic since they seemed had no difficulty in study. Success in study does not necessarily promise a satisfactory experience during a foreign student's sojourn abroad, although study is the main source of 
adjustment problems. To learn to bear the tension in a culturally different environment is a difficult task for a foreign student. Any meaningful interpersonal relationship may help a foreign student achieve a better adjustment.

At this point, my primary concern was how a social worker as professional helper could help the students who needed hel p but did not seek for hel p.

The other common answers were found out from the eight students who felt they were complete outsiders in the class room:

They seldom spoke English before. They felt English was very difficult. They found it difficult keeping up with American students.

As James Sawrey said (1971), " Withdrawal as a response to threat is a means of social isolation, which reduces or eliminates emotional tensions and anxieties resulting from social frustrations." Apparently the handicap of English language contributed to foreign students inability in relating to fellow students as well as their hardship in study. So, at this point, my pri mary concern was how a social worker could help foreign students toward decreasing language difficulty more efficiently.

Reach Out to Foreign Students Table XXI (p. 26) clearly indicated that very few students took good advantage of school counselors and foreign student advisors to help them in solving problems.

A college should have foreign student counselors who reach out to foreign students rather than waiting for them to come in for help.

${ }^{1}$ Sawrey, James., Psychology of Adjustment, Allyn and Bacon, Inc., Boston, 1971, p. 43. 
Both before and after their arrival campus, they should be well informed what academic and non-academic difficulties they may run into, and how they can be helped by using the appropriate provided services.

A welcome newcomers party for foreign students at the begining of each school year may help new and old students getting acquainted with one another and also getting to know counselors personally. The functions of foreign student counselling services can be introduced, face to face, at the party: In the meantime a session of question-and-answers could be held to draw counselors' attention to the real needs of students.

A college should encourage and support organizations of national groups as they can serve as a "home" for foreign students.

Offer Services -- Assistance and Guidance Besides reaching out to foreign students, so that they would be alert about the available resources and therefore use them to make better adjustment possible, foreign student counselors with the college's cooperation should offer various direct services to foreign students.

This research suggested that time was an important factor of language adjustment. Students who often had problems in communication felt they were isolated. In order to establish reciprocal intemersonal relationship with American students and develop the sense of being a part of the larger social whole, at first they have to be able to operate in English to a certain degree. It certainly would be helpful for them in getting used to listening and speaking English, if they could come to the United States about two or more weeks before school 
starts and live with an American family. Foreign student counselors should explore in the community the families that are willing to and able to offer room and board temporarily to foreign students.

This study also suggested that foreign students were very much concerned about their achieving a degree. Generally they were fairly good students as they studied hard and spent more time in study to overcome the language di fficulty. Most of them held a job not only in summer vacation but also during school year in order to support themselves. To help them add the other dimensions to their life -- making friends of the same and opposite sex, of the same and different nationalities; appreciating the natural world in this environment, and so on -- should be another concern of foreign student counselors.

Certain periodic social activities participated in by foreign students and fellow students who are interested in foreign culture should be held on campus, or off campus. The activities not only may offer good opportunities for them to exchange knowledge, increase mutual understanding, learn to accept custom differences, and make friends, but also can help foreign students' practicing and improving English, such as dancing party, dinner party, picnic, cultural festival, field trips.

A constant group activity, led by a well-trained social worker, should be available for foreign students to come freely to talk about their life, both on campus and off campus; to share their feelings, both happy and painful; and, to get emotional support through identifying with one another. The essential task of the social worker is to stimulate the group interaction rather than 
leading the group. Psychologist David Mechanic (1962) attempted to show how a group may be viewed as a major influence in understanding adaptive procsses. He suggested that a student's position within the structure of communication of which he is a member will affect what he learns about various alternatives for coping and defense. 1 Private counseling and advising should also be provided as a means to help them in coping with some personal problems.

In counseling sessions with foreign students, especially Chinese male students, a counselor needs to pay attention to their feel ings of homesickness. Chinese male students do not likely admit that they are homesick as they may be therefore considered unmanly and dependent. Foreign students do not, and should not, attempt complete assimilation. It is very understandable that a foreign student would feel homesick even if he adjusts to the new culture well. But homesickness has to be taken seriously by the counselor. As Kimball Young remarked (1952), "A common symptom of maladjustment to the new life is found in homesickness, a real malady to many students. While they usually conceal their real feelings from their associates, the uncertainty and sense of loss of emotional support of the family makes them unhappy and ill at ease." ${ }^{2}$ A foreign student counselor should put more emphasis on the reasons why they are homesick instead of the homesickness itself.

It seems wisest to keep student advising closely geared to the classroom

1Mechanic, David., Students Under Stress, The Free Press of Glencoe, N. Y. 1962. p. 215.

${ }^{2}$ Young, Kimball., Personality and Problems of Adjustment, AppletonCentury-Crofts, Inc., N.Y. 1952, p. 459. 
and everyday campus life. As students go to their professors when they have problems, to improve the system of faculty counseling is necessary. Advising students, both American students and foreign students, should be considered part of a college instructor's duties and professional responsibilities, not as extra tasks in addition to a heavy teaching load.

\section{RECOMMENDATIONS FOR FURTHER STUDY}

The whole problem of cross-cultural adjustment is so intensive and broad that no single research can be expected to encompass it. Some other practical areas in regard to Chinese college students' adjustment were not covered by this study, such as housing arrangement, financial aid, physical health, sexual adjustment, political adjustment, and so on. Appropriate researches on these subjects are necessary and recommended.

I believe that Chinese students would have felt easier and more willing to fill out the questionnaire, if I had written it in Chinese. The chances of misunderstanding questions would be decreased, too. Out of the total population of sixty-nine only eight students answered the open-ended questions very briefly. Combining the methods of questionnaire and interview, time permitting, would be a better way to collect data. 


\section{BIBLIOGRAPHY}

Blommers, Paul. and Lindquist, E. F., Statistical Methods in Psychology and Education, Houghton Mifflin Company, Boston, 1960.

Champion, Dean J., Basic Statistics for Social Research, Chamdler Publishing Company, Pennsylvania, 1970.

Cieslak, Edward Charnwood., The Foreign Student in American Colleges, Wayne University Press, Detroit, 1955.

Clarke, Helen I., and Ozawa, Martha., The Foreign Student in the United States - - with Special Reference to Martha ( Naoko Ozawa), The University of Wisconsin, Wisconsin, 1970.

Du Bois, Cora. , Foreign Students and Higher Education in the United States, American Council on Education, Washington D. C. , 1956.

Education and World Affairs, The Foreign Student: Whom Shall We Welcome, New York, N. Y. 1964.

Edwards, Allen L., Statistical Methods for the Behavioral Sciences, Rinehart and Company Inc., N. Y. 1954.

Freedman, Maurice, (Ed.), Family and Kinship in Chinese Society, Stanford University Press, Stanford, Calif., 1970.

Jehu, Derek., Learning Theory and Social Work, Routledge and Kegan Paul, London, 1967.

Lee, Rose Hum., The Chinese in the United States of American, Hong Kong University Press, Hong Kong, 1960.

Lindgren, Henry Clay., The Psychology of College Success, John Wiley \& Sons Inc., N. Y. 1969.

Mechanic, David, Students Under Stress, The Free Press of Glencoe, N.Y. 1962.

Morris, Richard T., The Two-way Mirror, The University of Minnesota Press, Minneapolis, 1960. 
Moore, Charles A. (Ed.), The Chinese Mind, University of Hawaii Press, Honolulu, 1967.

Sawrey, James. and Telford, Charles M. , Psychology of Adjustment, Allyn and Bacon, Inc., Boston, 1971.

Sing, Laura Lum. etc., Chinese Attitudes and Knowledge Concerning Social Service: A Survey of the Portland Chinese Community, Portland State University, Oregon, 1973.

Williamson, E. G. , How to Counsel Students, McGraw-Hill Book Company, Inc. , N.Y. 1939.

Yamamoto, Kaoru. (Ed. ), The College Student and His Culture: An Analysis, Houghton Mifflin Company, Boston, 1968.

Young, Kimball, Personality and Problems of Adjustment, Appleton-CentryCrofts, Inc., N.Y. 1952. 
親爱的同学:

我是波特淢大学(Portend State Chmin) 社会2作研究所 (ekroal of Social work) 二年级学生。两年前来自合诱。

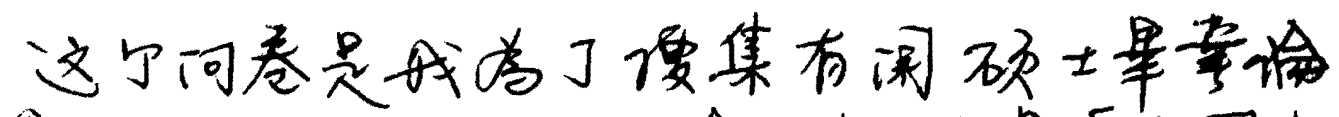

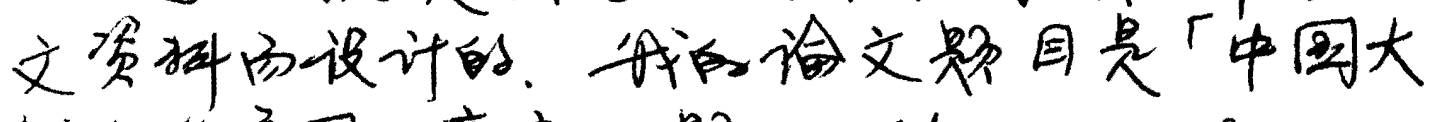

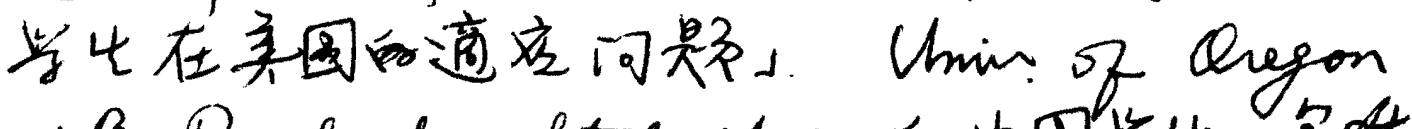
以及Portland Statectmon 的中国岁出, 包括 由公湾以这香港来的同学们，前是我访问 的对象。

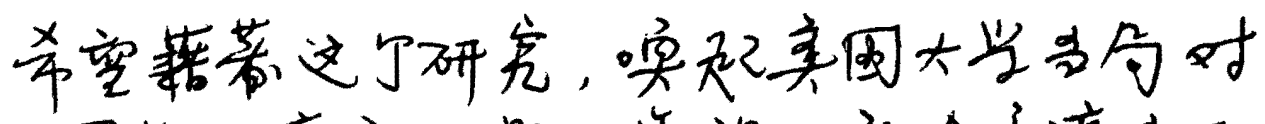

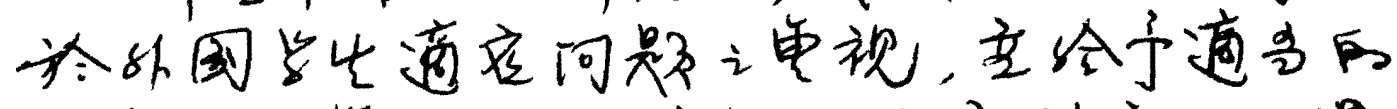

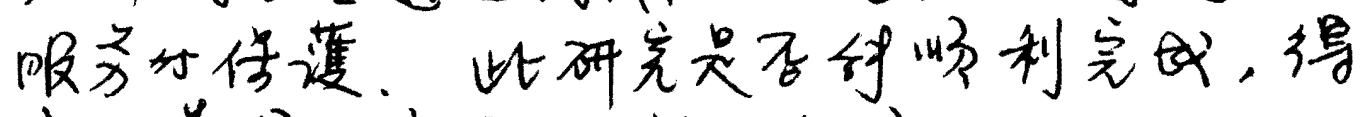
完全粦倍的充分合作支支对。

在此向售致最大的谢意！

㕌埱是 


\section{Chinese Student Surver \\ Terry Shu-Pang Hu \\ 1974}

QUESTIONNAIRE

1. Plesse do not put your name on the questionnaire.

2. Please answer questions as accurately and completely as you can. Our understanding depends upon each person's truly reflecting the real situation.

3. You may answer the questions from No. 24 to No. 28 in Chinese, if you feel you can express yourself better in Chinese.

4. Please check the response category which comes closest to your situation, or fill in briefly what comes closegt to the truth.

5. I thank you very much for your kind cooperation. 
1. Sex Male

Pemale

2. Age lagt birthday

3. Name of University Univereity of Oregon Portland State Univ.

4. Student status _Under-graduate Graduate

5. Major field

6. Home residence Taiwan, Rep. of China Hong Kong

7. Length of time in the United States (please do not count the time when you went back home for visit) Year (s) and Month (s)

8. Housing arrangement

a. If you have a roommate or roommates, including your spouse, who live with you in the same room or house, they are - Chinges only Americans only Chinses and Amertcans

Other

b. If you do not have any roommates, the people who live with you in the same domitory or apartment are Chinese mostly Anoricano mostly 
9. Narital status -

Harried, liring with spouse

Married, not living with spouse

Divorsed

Other

10. If you are not married 配偶意中人

a. Do you have a potential apbuse in your mind? -

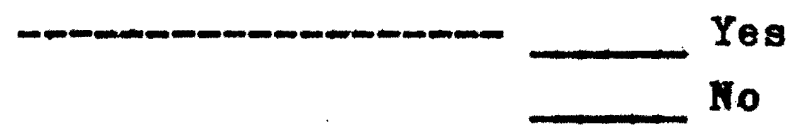

b. If no, where do jou plen to look for one?

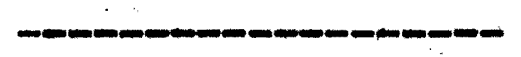
Back home In the United States Other

c. Tetting married and achieving a degree, which one are you more concerned about?

Getting married

Achiering a degree

d. If you have a very close American girlfriend or boyfriend, not including Americam borm Chinese, and you plan to get married to each other, to your knowledge, what will be your parents' attitudes towards 1t? -...Strongly against Somewhat against Neutual Somewhat favorable Very favorable 
11. Have you ever held a job during school year or summer vacation since you came to the United States?

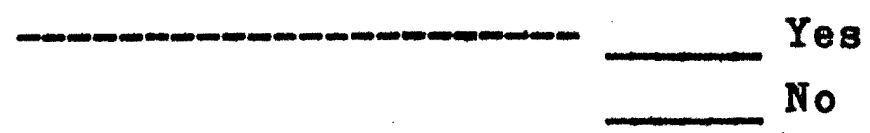

a. If yes, the job(s) is

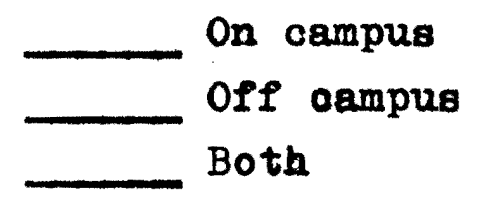

b. What did you do briefly, and in that sotting? (1.e. waiter in coffee house)

c. How do you feel of mentioning about your job(s) in front of the people you know? Very ashamed A little bit ashamed Not ashamed Proud of yourself

12. Please check sources of financial support this year. Check more than one if applicable.

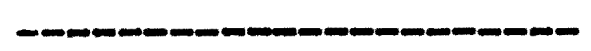
Self, working Self, savings Your family Govermmental aid Other private aid

Other

13. Before you came to the United States, did you have a chance to converse with people in English? 


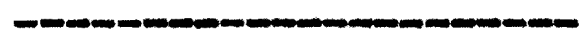

Very often

Often

Sometimes

Seldom

Never or elmost never

14. a. When you communicate with American professors and classmates, do you have problems understanding or being understood by them?

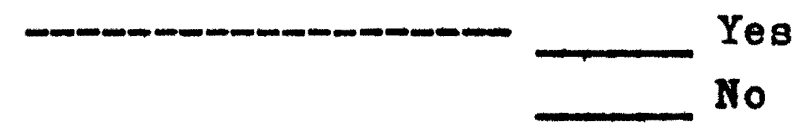

b. If yes, how often?

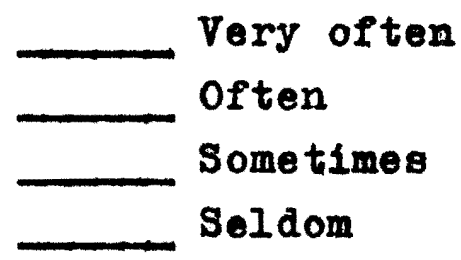

15. How did you feel about English language when rou first came to the United States? For me, it was -
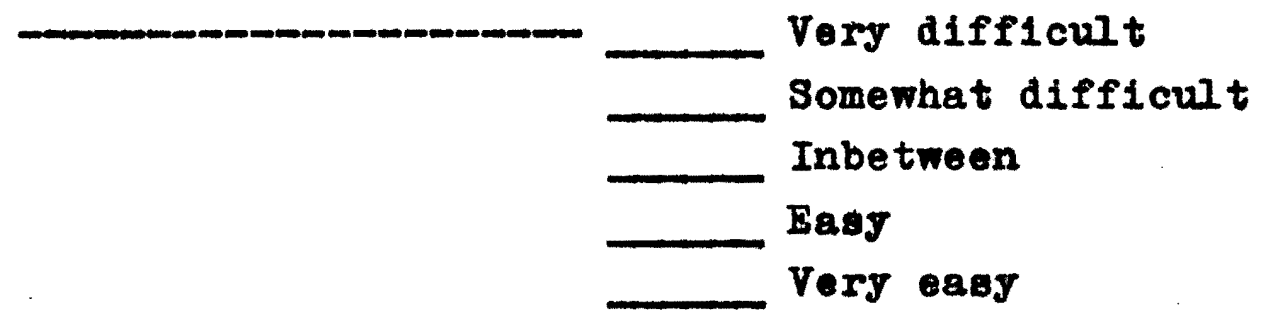

16. Compared to the time when you firat came to the United States, how do you think of your English language ability now? It is -Much improved Somewhat improved About the same Iittle improved Very little improved 
17. Hor do you feel about keeping up academlcelly with American students in your calss? It is

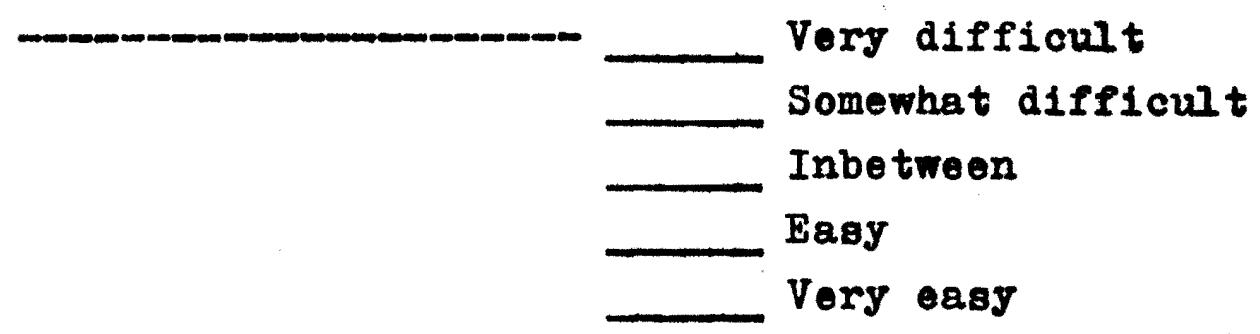

18. In your opinion, where do you otand in your class?
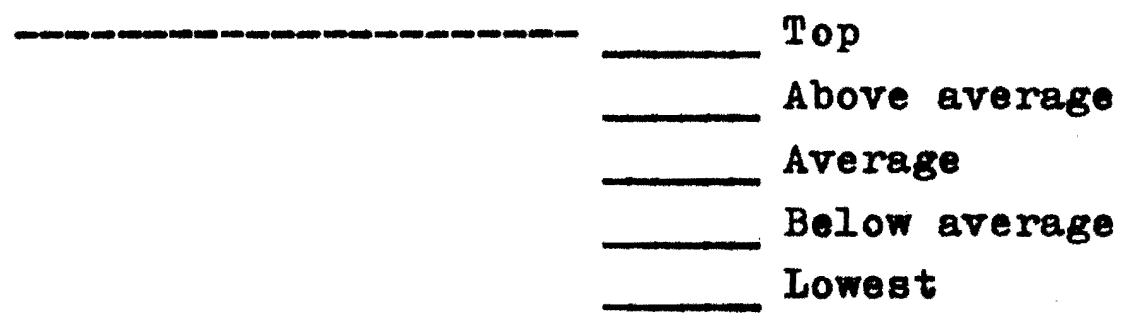

19. How do you feel about yourself nost of the time when you are with classmates? A member of the group, and accepted by them A member of the group, but isolated from them An outsider

20. Do you feel homesick ? Very often Often Sometimes Seldom Never or almost never

21. When you have problems in daily life, whom do you talk with or get help from? Check more than one if applicable. Gutivas friend American school friend American family School counselor 


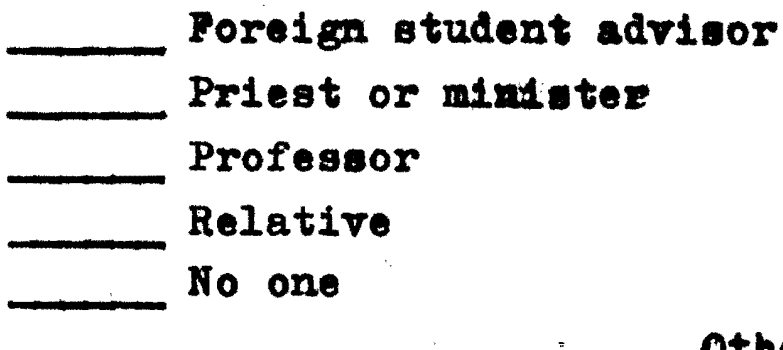

Other

22. a. How many times a year do you go to the foreign student advisor office?

Once

2-5 times

Hore than 5 times

b. The reasons for going are: (Chock more than one if applicable) Extending viea

Applfing for working permiasion

Applying for ensilient certiflcate Applying for finanoial as Social visit

Other

23. In terms of the way your home town 100ks at sbciál position, where do you think your immediate family 出身家庭 stande? Vory high

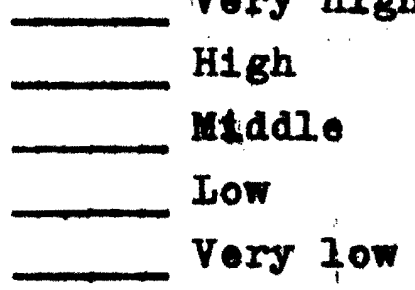

a.

24. Do you plan to go back home after you have finished :... your study? -

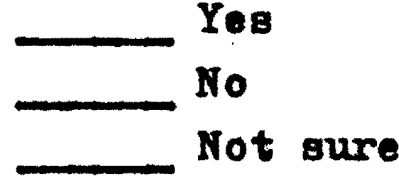


b. Whr?

25. What services do you think that the American colleges onpuld provide for foreign studente to help thom

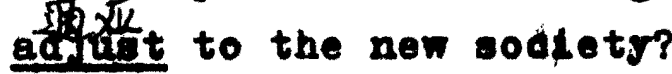

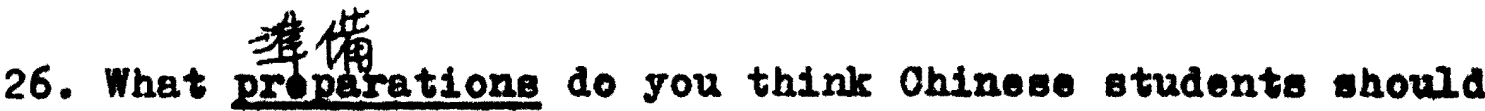
have don pefore they came to the United States whioh

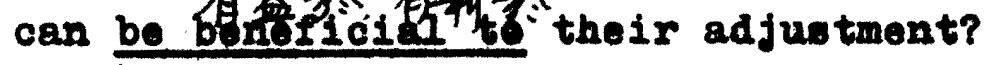

27. Please answer the question oither a. or $b$.

a. If you think so far you hare done a good job in adjusting yourself to smerican society, what do you think are the important factors which make the. good adjustment possible? 
b. If you think too far you have not done a good job in adjusting jourself to Amerloan society, what do you think will be most helpful for you to improve your adjus tment?

28. Is there something important not covered by the questionnaire? Please write down what you would like to say. 